\title{
Growth, Gas Exchange, and Chlorophyll Fluorescence of Four Ornamental Herbaceous Perennials during Water Deficit Conditions
}

\author{
Terri Starman and Leonardo Lombardini \\ Department of Horticultural Sciences, Texas A\&M University, College Station, TX 77843-2133
}

\begin{abstract}
AdDitional INDEX words. $\mathrm{F}_{\mathrm{v}} / \mathrm{F}_{\mathrm{m}}$, Lantana camara, Lobelia cardinalis, Salvia farinacea, Scaevola aemula, water use efficiency

Aвstract. A study was conducted to characterize the morphological and physiological responses of four herbaceous perennial species subjected to two subsequent drought cycles. Lantana camara L. 'New Gold' (lantana), Lobelia cardinalis L. (cardinal flower), Salvia farinacea Benth. 'Henry Duelberg' (mealy sage), and Scaevola aemula $\mathrm{R}$. Br. 'New Wonder' (fan flower) were subjected to two consecutive 10-day drought cycles. Growth response, leaf gas exchange, and chlorophyll fluorescence were measured during the experiment. The morphology of L. cardinalis and L. camara was not affected by drought, while $S$. farinacea had reductions in plant height and leaf area and $S$. aemula had reductions in dry weight. Overall, plant growth and development continued even when substrate water content was reduced to 0.13 $\mathrm{mm}^{3} \cdot \mathrm{mm}^{-3}$, which indicated a level of substrate water below container capacity was sufficient for greenhouse production of these species. The drought treatments had little effect on the photochemical efficiency $\left(F_{v} / F_{m}\right)$ of Photosystem II. An increase in minimal fluorescence $\left(F_{0}\right)$ was observed in $S$. aemula on the last day of the second cycle. Drought treatment caused increased leaf-level water use efficiency (WUE) at the end of the first cycle in $L$. cardinalis and $S$. aemula, but not in L. camara and $S$. farinacea. Plants of L. camara, S. farinacea, and $S$. aemula that had received drought during both cycles became more water use efficient by the end of the second cycle, but $L$. cardinalis did not.
\end{abstract}

In recent years, reduced water availability and increased water prices have prompted municipalities of arid regions to develop programs to reduce water inputs while maintaining the attractiveness of urban landscapes (Ball Publishing, 2003; Kuack, 2003; Welch, 1989; Welsh et al., 2000). The term xeriscape was created to indicate a type of low-maintenance landscape achieved by choosing appropriate plants and modifying the different aspects of landscape designing (soil type, watering, mulching, and maintenance) (Denver Water Department, 2005). Plants that are good candidates for xeriscapes are usually native to dry environments and possess physiological, morphological, anatomical and/or phenological characteristics for responding to low water conditions. Anatomical and morphological features, such as reduced plant size, small, dissected leaves, pubescence, and a thick cuticle help reduce boundary layer resistance and non-stomatal water losses (Henckel, 1964; Kramer and Boyer, 1995). Among the physiological adaptations are decreased transpiration, CAM metabolism, synthesis and active accumulation of compatible solutes, and increased level of abscisic acid (Henckel, 1964; Hsiao, 1973; Iljin, 1957).

The herbaceous perennials compared in the study were two native Texas species (Lobelia cardinalis and Salvia farinacea), one naturalized tropical species (Lantana camara) and one exotic species (Scaevola aemula) commonly used in southern landscapes. While S. farinacea, L. camara, and S. aemula are more adapted to water deficit conditions (Armitage, 2001; Knowles et al., 1993), L. cardinalis grows mainly on moist soils (Welch, 1989). Salvia

Received for publication 16 Dec. 2005. Accepted for publication 25 Feb. 2006 This project was funded in part by the Texas Agricultural Experiment Station and a grant from Texas Ornamental Enhancement Endowment (TOEE). The authors wish to acknowledge the contributions of Kristen L. Eixmann, Floriculture Research Assistant at Texas A\&M for her technical assistance. Mention of a trademark, proprietary product, or vendor does not constitute a guarantee or warranty of the product by the authors, the Texas A\&M Univ., the Texas Agricultural Experiment Station, or sponsors of the research and does not imply its approval to the exclusion of other products or vendors that also may be suitable. farinacea is a drought-tolerant species well-adapted to southern landscapes in U.S. Dept. of Agriculture hardiness zones 7 through 10 (Knowles et al., 1993). Salvia farinacea has pubescent stems, leaves and calyces, and is widespread in cultivation (Griffiths, 1994). Lantana camara has pubescent and scabrous leaves (Griffiths, 1994) and it continues to produce dense heads of flowers throughout the summer heat (Armitage, 2001). Scaevola aemula has puberulent, succulent leaves and it is native to southern and eastern Australia (Griffiths, 1994). Plants flower through the hottest summers and rarely lose turgor (Armitage, 2001). However, wilting can be irreversible (M.A. Arnold, personal communication). Recently, S. aemula has been successful in the European and American market, but very little is known about the growth and physiology of this species (Bhalla and Sweeney, 1998). A study of four native Hawaiian species of Scaevola found water use efficiency was lesser compared to four species of Euphorbia, regardless of whether they were indigenous to very dry or very wet habitats (Robichaux and Pearcy, 1984). Lobelia cardinalis has glossy leaves (Griffiths, 1994), is found in wetland habitats throughout much of North America and has a long history of cultivation (Thompson and Lammers, 1997).

Our objective was to explore the mechanisms behind the premise that plants native to dry regions are drought tolerant. We postulated that greenhouse studies could provide insight about the physiology of plants as a basis for selecting species for dry landscapes. Gas exchange, primary photochemistry, and growth of four herbaceous perennial species with landscape horticulture market potential were examined during two water deficit cycles from liner/seedling plug stage to mature plants.

\section{Material and Methods}

Plant material and growth conditions. Plant materials included L. camara 'New Gold', L. cardinalis, S. farinacea 'Henry Duelberg', and S. aemula 'New Wonder'. Lantana camara 
'New Gold' originated as a seedling propagated by a nurseryman in Dallas, Texas, at Tawakoni Plant Farm/North Haven Gardens (J.M. Parsons, personal communication). Seedlings of L. cardinalis were grown from seeds originally collected from a naturalized stand located at the Prairie Chapel Ranch in Crawford, Texas (W.C. Welch, personal communication). Cuttings of S. farinacea 'Henry Duelberg' originated from cuttings collected from a cemetery located in LaGrange, Texas (G. Grant, personal communication). Scaevola aemula 'New Wonder' liners were obtained from a commercial propagator (EuroAmerican Propagators, Bonsall, Calif.).

Eighty rooted liners or seedling plugs of each species were grown in the glass greenhouse for 14 to $28 \mathrm{~d}$ in 0.7 -L pots $(11.0$ $\mathrm{cm}$ top diameter $\times 7.6 \mathrm{~cm}$ bottom diameter $\times 9.5 \mathrm{~cm}$ height) until transplanting into 1.9-L containers $(14.7 \mathrm{~cm}$ top diameter $\times 10.8$ $\mathrm{cm}$ bottom diameter $\times 14.4 \mathrm{~cm}$ height) on 10-12 Mar. 2004. The substrate was soilless medium (ProMix BX; Premier Horticulture, Red Hill, Pa.). Lantana camara were pinched and S. farinacea terminal flower buds were removed to increase branching. Plants were irrigated as needed and fertilized with each watering at 200 $\mathrm{mg} \cdot \mathrm{L}^{-1} \mathrm{~N}$ using $15 \mathrm{~N}-3.4 \mathrm{P}-7.1 \mathrm{~K}$ (Peters Professional; Scotts-Sierra, Marysville, Ohio) from arrival until 24 Mar. and then using 20N-4.4P-16.6K (Peters Professional). Greenhouse temperature was $20.6 \pm 1.4{ }^{\circ} \mathrm{C}$ day/17.0 $\pm 0.4{ }^{\circ} \mathrm{C}$ night measured with a datalogger (Hobo H8; Onset Computer Corp., Bourne, Mass.). Photosynthetic photon flux density $(P P F D)$ was measured with the quantum sensor on the leaf cuvette of the infrared gas analyzer (model 6400; LI-COR, Lincoln, Nebr.) and averaged $443 \pm 75$ $\mu \mathrm{mol} \cdot \mathrm{m}^{-2} \cdot \mathrm{s}^{-1}$ during mid-day gas exchange measurements.

Treatment APPLICATION AND EXPERIMENTAL DESIGN. Fifty plants per species of uniform size and characteristics were selected and arranged in a completely randomized design. The medium of all plants was brought to container capacity by irrigation when treatments were initiated. The first drought cycle was started 30 Mar. when roots were well established. There were 25 plants per treatment and two watering treatments, irrigation at container capacity [control (C)] and withhold irrigation [drought (D)]. To determine the magnitude of the drought treatment, a preliminary experiment was conducted in which plants were watered, weighed daily and then allowed to wilt. At wilting, pot weight averaged $50 \%$ of the initial weight.

Throughout the experiment, volumetric water content of the upper $6 \mathrm{~cm}$ of the substrate was determined every other day using a Theta Probe (type HH2; Delta-T Devices, Cambridge, U.K.), set on the organic soil setting. For each species, five of the plants assigned to D were chosen randomly to monitor the amount of water lost by evapotranspiration. After irrigation, pots were allowed to drain for $1 \mathrm{~h}$ and then reweighed. The new weights were used as the value to determine $50 \%$ of initial weight (IW). When the combined weight of five indicator pots had decreased below $50 \%$ IW, the $50 \%$ substrate water content was restored by re-supplying the amount of water lost in one day. At the end of the first cycle, the five indicator plants per treatment for each species were harvested destructively, while the remaining plants of both $\mathrm{C}$ and $\mathrm{D}$ were irrigated to container capacity.

Data collected from the indicator plants were total fresh and dry weight, number of flowers or inflorescences, and flowering stems ( $S$. aemula only), height and width index (first cycle) or height or width index (second cycle, depending on growth habit of the species, either upright or trailing). Plant height was measured from bench to top of the plant. Width index was the average of two plant width measurements across the plant canopy perpen- dicular to each other. After all leaves were removed, total area was measured with a leaf area meter connected with a transparent belt conveyor (models LI-3000A and LI-3050A; LI-COR). Leaf area ratio and specific leaf area were calculated by dividing the leaf area of five leaves by their dry and fresh weight, respectively. Plants were cut at soil level and fresh weight was measured gravimetrically. Plant dry weight was measured gravimetrically after $72 \mathrm{~h}$ in oven at $75^{\circ} \mathrm{C}$.

The second cycle was initiated the day after rewatering to container capacity. For the second drought cycle, 20 plants from each of the C and D groups of the first cycle were randomly split in two groups that were assigned to two new C and D treatments. Consequently, there were four treatments: plants grown in wellwatered substrate in both cycles (CC), plants well-watered in the first cycle and subjected to drought in the second cycle (CD), plants subjected to drought in the first cycle and well-watered in the second cycle (DC), and plants subjected to drought in both cycles (DD). Before the initiation of the second cycle, five indicator pots were selected for each species for each treatment (i.e., 20 plants per species). The second drought cycle was imposed as described for the first drought cycle. At the end of the second cycle, five plants per treatment per species were harvested destructively. In addition to the previously described parameters, leaf dry weight and total leaf area were measured.

Chlorophyll Fluorescence. At the beginning of the first drought cycle, the tip of the two youngest fully expanded leaves of each plant was dotted using a permanent marker. Leaf chlorophyll fluorescence measurements were performed using an open infrared gas-exchange system with an integrated fluorescence chamber head (model 6400-40; LI-COR). One marked leaf of five plants per treatment was dark-adapted in lightweight cuvettes (model 9964-061; LI-COR) for at least $20 \mathrm{~min}$ prior to fluorescence measurement (Greer, 1995). At the time of measurements, leaf temperature ranged between 24 and $27{ }^{\circ} \mathrm{C}$ (depending on air temperature), and chamber air $\mathrm{CO}_{2}$ was set at $360 \mu \mathrm{L} \cdot \mathrm{L}^{-1}$. To measure the dark-adapted fluorescence value (minimal fluorescence, $\mathrm{F}_{\mathrm{o}}$ ), each leaf was illuminated with an extremely dim light $\left(1-2 \mu \mathrm{mol} \cdot \mathrm{m}^{-2} \cdot \mathrm{s}^{-1}\right)$. Maximal fluorescence $\left(\mathrm{F}_{\mathrm{m}}\right)$ was determined after illumination with a brief $(0.8 \mathrm{~s})$ pulse of saturating light intensity $\left(6000 \pm 25 \mu \mathrm{mol} \cdot \mathrm{m}^{-2} \cdot \mathrm{s}^{-1}\right)$. The variable fluorescence $\left(\mathrm{F}_{\mathrm{v}}=\mathrm{F}_{\mathrm{m}}-\mathrm{F}_{\mathrm{o}}\right)$ allowed calculation of the maximal photochemical efficiency $\left(\mathrm{F}_{\mathrm{v}} / \mathrm{F}_{\mathrm{m}}\right)$, which corresponds to the fraction of absorbed photons that are used for photochemistry by a dark-adapted leaf. The electron transport rate [ETR (i.e., the actual flux of photons driving photosynthesis)] was also determined using the fluorescence chamber head. Chlorophyll fluorescence was measured on day $2,4,6,8$, and 10 of the first drought cycle and on day 0,2 , 6,8 , and 10 of the second cycle.

Gas exchange. Single-leaf gas exchange measurements commenced day 0 of the first cycle and thereafter were always coupled with measurements of leaf chlorophyll fluorescence. In both cycles, single-leaf net carbon dioxide assimilation rate (A), transpiration rate $(\mathrm{E})$, and stomatal conductance $\left(\mathrm{g}_{\mathrm{s}}\right)$ were determined simultaneously with the determination of fluorescence parameters of light-adapted leaves using the same gas exchange system and the integrated fluorescence chamber head. Single leaf measurements were taken at $600 \mu \mathrm{mol} \cdot \mathrm{m}^{-2} \cdot \mathrm{s}^{-1} P P F D$, supplied by a red/blue light source (model 6400-02B; LI-COR) on the adaxial leaf surface. The ratio between the amounts of $\mathrm{CO}_{2}$ assimilated and the amount of water lost by transpiration was calculated to indicate the instantaneous water use efficiency (WUE). Vapor pressure deficit (VPD) was recorded at the time of gas exchange 
data collection using the same infrared gas analyzer (model 6400-40; LI-COR).

Photosynthetic light response curves were determined on one marked leaf per plant using the same gas exchange system described above. Light levels were obtained using the red/blue light source, which was set to provide increasing PPFD levels $(0,50$,

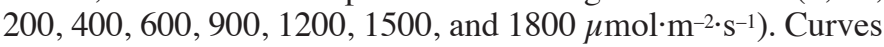
were performed on day 10 of the second drought cycle. Three plants per treatment were used. Measurements were performed in the greenhouse between 0900 and $1300 \mathrm{HR}$, under the similar environmental conditions as single-leaf measurements were conducted. Leaves were allowed to adapt to each light level for two minutes before each data point was recorded. To fit each light response curve, the nonrectangular hyperbola function described by Lambers et al. (1998) was used

$\mathrm{A}=\frac{\Phi \cdot I+\mathrm{A}_{\text {max }}-\sqrt{\left\{\left(\Phi \cdot I \cdot \mathrm{A}_{\text {max }}\right)^{2}-4 \cdot \Theta \cdot \Phi \cdot I \cdot \mathrm{A}_{\text {max }}\right\}}}{2 \cdot \Theta}-\mathrm{R}_{\mathrm{d}}$

where $\mathrm{A}\left(\mu \mathrm{mol} \cdot \mathrm{m}^{-2 \cdot} \cdot \mathrm{s}^{-1}\right)$ is the net $\mathrm{CO}_{2}$ assimilation rate, $\Phi$ is the apparent quantum yield $\left(\mathrm{mol} \cdot \mathrm{mol}^{-1}\right), I$ is the incident irradiance $\left(\mu \mathrm{mol} \cdot \mathrm{m}^{-2} \cdot \mathrm{s}^{-1}\right), \mathrm{A}_{\max }\left(\mu \mathrm{mol} \cdot \mathrm{m}^{-2} \cdot \mathrm{s}^{-1}\right)$ is the light-saturated rate of gross $\mathrm{CO}_{2}$ assimilation [net $\mathrm{CO}_{2}$ assimilation plus dark respiration, $\mathrm{R}_{\mathrm{d}}\left(\mu \mathrm{mol} \cdot \mathrm{m}^{-2} \cdot \mathrm{s}^{-1}\right)$ ] at infinitely high irradiance, and $\Theta$ (dimensionless) is the curvature factor.

STATistical anAlysis. For the first cycle, when only two treatments were applied, treatments were compared using a $t$ test. For the second cycle, data were subjected to analysis of variance (ANOVA) and, where applicable, means were separated using Fisher's least significance difference (LSD) at $P \leq 0.05$ using SAS software (SAS Institute, Cary, N.C.).

\section{Results}

Time to $50 \%$ IW was $6 \mathrm{~d}$ for all species during the first cycle, while in the second cycle time varied between 4 and $6 \mathrm{~d}$ depending on species and treatment. Trends of substrate water content were similar for all the species and only results for L. cardinalis are shown (Fig. 1). In the first cycle, substrate water content of $\mathrm{C}$ stayed constant between 0.55 and $0.65 \mathrm{~mm}^{3} \cdot \mathrm{mm}^{-3}$, while it decreased rapidly in $\mathrm{D}$ beginning day 2 until it reached 0.13 $\mathrm{mm}^{3} \cdot \mathrm{mm}^{-3}$ at day 10 . Throughout the second cycle, substrate water content was similar for CC and DC. By day 2, substrate water content of CD and DD was similar and decreased compared to CC and DC. By day 10, substrate water content averaged 0.59 $\mathrm{mm}^{3} \cdot \mathrm{mm}^{-3}$ in CC and DC and $0.18 \mathrm{~mm}^{3} \cdot \mathrm{mm}^{-3}$ in CD and DD. Lobelia cardinalis, S. farinacea, and $S$. aemula plants wilted before each watering, but L. camara plants did not show observable signs of drought. Drought stress did not cause defoliation or leaf necrosis. Vapor pressure deficit (VPD) averaged $0.96 \mathrm{kPa}$ during the first cycle and $1.06 \mathrm{kPa}$ in the second, with a peak of $1.67 \mathrm{kPa}$ on day 6 (Fig. 1).

After the first drought cycle, there was a difference between $\mathrm{C}$ and D plants for total fresh weight for three species (Table 1). Drought-treated plants of L. camara, L. cardinalis, and S. farinacea had less fresh weight than control plants. There was no difference in the fresh weight of $S$. aemula plants. Other morphological differences due to treatment were a reduction in plant width of drought-treated L. camara and an increase in inflorescence number of drought-treated S. aemula. Scaevola aemula was the only species with all plants in flower at that time. All other measured variables were the same regardless of drought treatment.

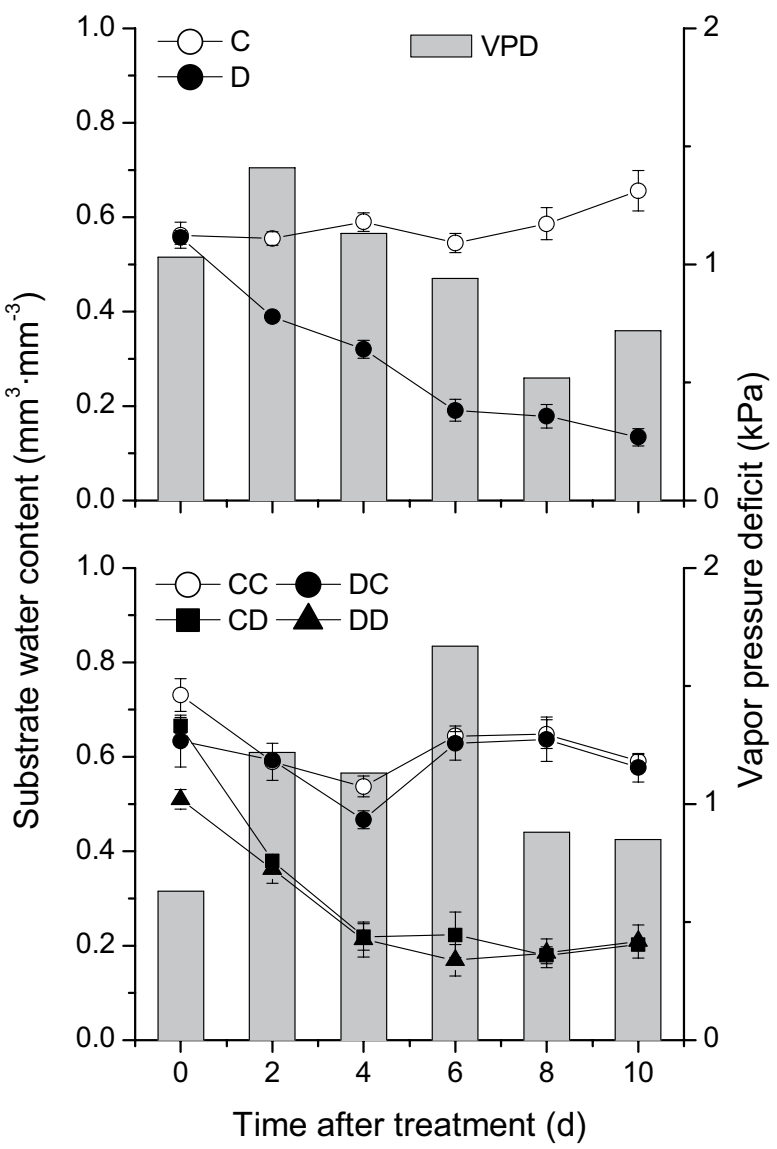

Fig. 1. Substrate water content $\left(\mathrm{mm}^{3} \cdot \mathrm{mm}^{-3}\right)$ of five potted Lobelia cardinalis subjected to two consecutive 10-d drought cycles and vapor pressure deficit (VPD) measured during gas exchange analysis. First cycle (top): $\mathrm{C}=$ control (well-watered), $\mathrm{D}=$ drought. Second cycle (bottom): $\mathrm{CC}=$ plants grown in well-watered substrate in both cycles, $\mathrm{CD}=$ plants well-watered in the first cycle and subjected to drought in the second cycle, $\mathrm{DC}=$ plants subjected to drought in the first cycle and well-watered in the second cycle, DD = plants subjected to drought in both cycles. Error bars indicate SE.

By the end of the second cycle all species had developed to reproductive, mature plants. The second drought cycle did not affect the growth and morphology of either L. cardinalis or $L$. camara (data not shown). Lobelia cardinalis averaged $42.2 \mathrm{~cm}$ in height and two inflorescences and L. camara averaged $77.1 \mathrm{~cm}$ in width and had eight inflorescences (data not shown). Height of $S$. farinacea was greatest for CC and least for DD, while intermediate for DC and CD (Table 2). The fresh weight in CD and DD was smaller than in CC and DC. Total leaf area for CC was greater than for CD and DD, which were similar to DC. Specific leaf area was greatest in DD and least in DC. All plants had four inflorescences and similar dry weight and leaf area ratio. Total fresh and dry weight and leaf area of S. aemula were greatest in DC (Table 2). DD and CD had the least fresh weight and DD had less dry weight than all other treatments. Scaevola aemula averaged $57.7 \mathrm{~cm}$ in width and had 19 flowers.

In general, the efficiency of photosystem II (PSII), expressed as $\mathrm{F}_{\mathrm{v}} / \mathrm{F}_{\mathrm{m}}$, was not affected by the drought in either the first or second cycle (Fig. 2). The only exceptions were observed in $L$. camara and L. cardinalis in the first and second drought cycle, respectively. Lantana camara showed a reduction $(2.4 \%)$ of $\mathrm{F}_{\mathrm{v}} / \mathrm{F}_{\mathrm{m}}$ in D vs. C on day 8. Chlorophyll fluorescence parameters of $L$. cardinalis were affected by drought on day 0 of the second cycle, when $\mathrm{F}_{\mathrm{v}} / \mathrm{F}_{\mathrm{m}}$ of $\mathrm{CD}$ and DD were greater than CC (Fig. 
Table 1. Effect of one 10-d-long drought treatment (first cycle) on plant height, width index, inflorescence number, total fresh and dry weight, and specific leaf area of four herbaceous perennial species (Lantana camara, Lobelia cardinalis, Salvia farinacea, and Scaevola aemula).

\begin{tabular}{|c|c|c|c|c|c|c|c|}
\hline Species & Treatment $^{\mathrm{z}}$ & $\begin{array}{c}\text { Plant ht } \\
(\mathrm{cm})\end{array}$ & $\begin{array}{r}\text { Width } \\
\text { index } \\
(\mathrm{cm})\end{array}$ & $\begin{array}{c}\text { Inflorescence } \\
\text { no. }\end{array}$ & $\begin{array}{c}\text { Total } \\
\text { fresh wt } \\
(\mathrm{g})\end{array}$ & $\begin{array}{c}\text { Total } \\
\text { dry wt } \\
(\mathrm{g})\end{array}$ & $\begin{array}{l}\text { Specific } \\
\text { leaf area } \\
\left(\mathrm{cm}^{2} \cdot \mathrm{g}^{-1}\right)\end{array}$ \\
\hline \multirow[t]{3}{*}{ L. camara } & $\mathrm{C}$ & 30.5 & 59.7 & 0.4 & 48.9 & 20.4 & 57.4 \\
\hline & $\mathrm{D}$ & 29.9 & 50.4 & 0.4 & 32.8 & 19.0 & 59.7 \\
\hline & Significancey & NS & $*$ & NS & $*$ & NS & NS \\
\hline \multirow[t]{3}{*}{ L. cardinalis } & $\mathrm{C}$ & 34.6 & 28.8 & 0 & 39.3 & 15.5 & 49.2 \\
\hline & $\mathrm{D}$ & 32.2 & 26.9 & 0 & 24.1 & 14.7 & 51.6 \\
\hline & Significance & NS & NS & NS & $*$ & NS & NS \\
\hline \multirow[t]{3}{*}{ S. farinacea } & $\mathrm{C}$ & 53.6 & 36.3 & 0 & 50.2 & 20.4 & 59.1 \\
\hline & $\mathrm{D}$ & 50.6 & 34.5 & 0 & 41.3 & 19.3 & 62.2 \\
\hline & Significance & NS & NS & NS & $*$ & NS & NS \\
\hline \multirow[t]{3}{*}{ S. aemula } & $\mathrm{C}$ & 28.1 & 42.9 & 3.4 & 53.6 & 16.6 & 22.5 \\
\hline & $\mathrm{D}$ & 25.5 & 44.5 & 9.2 & 49.5 & 16.5 & 22.6 \\
\hline & Significance & NS & NS & $*$ & NS & NS & NS \\
\hline
\end{tabular}

${ }^{2} \mathrm{C}=$ control (well-watered), $\mathrm{D}=$ drought.

yMean separation by $t$ test $(P=0.05)$.

ss, *Indicate nonsignificant or significant at $P \leq 0.05$, respectively; $\mathrm{n}=5$.

Table 2. Effect of two consecutive 10-d drought cycles on plant size, flower number, total fresh and dry weight, total leaf area, leaf area ratio and specific leaf area of Salvia farinacea 'Henry Duelberg' and Scaevola aemula 'New Wonder.'

\begin{tabular}{|c|c|c|c|c|c|c|c|c|}
\hline Species & Treatment $^{2}$ & $\begin{array}{l}\text { Plant size } \\
\quad(\mathrm{cm})\end{array}$ & $\begin{array}{c}\text { Flower } \\
\text { no. }^{x}\end{array}$ & $\begin{array}{c}\text { Total } \\
\text { fresh wt } \\
(\mathrm{g})\end{array}$ & $\begin{array}{l}\text { Total } \\
\text { dry wt } \\
(\mathrm{g})\end{array}$ & $\begin{array}{c}\text { Total leaf } \\
\text { area } \\
\left(\mathrm{cm}^{2}\right)\end{array}$ & $\begin{array}{c}\text { Leaf area } \\
\text { ratio } \\
\left(\mathrm{cm}^{2} \cdot \mathrm{g}^{-1}\right)\end{array}$ & $\begin{array}{c}\text { Specific leaf } \\
\text { area } \\
\left(\mathrm{cm}^{2} \cdot \mathrm{g}^{-1}\right)\end{array}$ \\
\hline \multirow[t]{5}{*}{ S. farinacea } & $\mathrm{CC}$ & $128.1 \mathrm{a}^{\mathrm{w}}$ & 4 & $111.3 \mathrm{a}$ & 20.1 & $2620.8 \mathrm{a}$ & 330.4 & $61.5 \mathrm{bc}$ \\
\hline & $\mathrm{DC}$ & $119.4 \mathrm{~b}$ & 4 & $100.9 \mathrm{a}$ & 19.0 & $2401.3 \mathrm{ab}$ & 320.8 & $59.5 \mathrm{c}$ \\
\hline & $\mathrm{CD}$ & $116.4 \mathrm{~b}$ & 4 & $83.3 \mathrm{~b}$ & 17.1 & $2133.3 \mathrm{~b}$ & 360.9 & $65.6 \mathrm{ab}$ \\
\hline & $\mathrm{DD}$ & $103.3 \mathrm{c}$ & 4 & $75.4 \mathrm{~b}$ & 19.7 & $1986.3 \mathrm{~b}$ & 339.5 & $66.9 \mathrm{a}$ \\
\hline & Significance & $* * *$ & NS & $* * *$ & NS & $*$ & NS & $*$ \\
\hline \multirow[t]{5}{*}{ S. aemula } & $\mathrm{CC}$ & 55.4 & 15 & $95.4 \mathrm{~b}$ & $9.2 \mathrm{ab}$ & $1387.8 \mathrm{~b}$ & 245.1 & 24.4 \\
\hline & $\mathrm{DC}$ & 58.1 & 22 & $108.2 \mathrm{a}$ & $10.2 \mathrm{a}$ & $1720.6 \mathrm{a}$ & 289.0 & 24.8 \\
\hline & $\mathrm{CD}$ & 59.2 & 18 & $87.2 \mathrm{bc}$ & $8.5 \mathrm{~b}$ & $1292.6 \mathrm{~b}$ & 274.2 & 22.7 \\
\hline & $\mathrm{DD}$ & 58.1 & 20 & $81.2 \mathrm{c}$ & $3.0 \mathrm{c}$ & $1270.6 \mathrm{~b}$ & 287.5 & 23.4 \\
\hline & Significance & NS & NS & $* * *$ & $* * *$ & $* *$ & NS & NS \\
\hline
\end{tabular}

${ }^{2} \mathrm{CC}=$ plants grown in well-watered substrate in both cycles, $\mathrm{CD}=$ plants well-watered in the first cycle and subjected to drought in the second cycle, $\mathrm{DC}=$ plants subjected to drought in the first cycle and well-watered in the second cycle, DD = plants subjected to drought in both cycles.

yFor $S$. farinacea, plant size is expressed as height, whereas for $S$. aemula, which has a trailing habit, size was measured as width index.

xIn $S$. farinacea number of inflorescences was collected.

wMeans followed by different letters are significantly different at $P \leq 0.05$ by Fisher's LSD.

Ns, ${ }^{*}, *, * * *$ Nonsignificant or significant at $P \leq 0.05,0.01$ or 0.001 , respectively; $\mathrm{n}=5$.

2). On day 0 of the second cycle, ETR in L. cardinalis $\mathrm{CD}$ and DD was lesser than CC and DC (data not shown). No detectable effects of drought were observed in $\mathrm{F}_{\mathrm{v}} / \mathrm{F}_{\mathrm{m}}$ of either $S$. farinacea or S. aemula. However, on day 10 of the second cycle, $\mathrm{F}_{\mathrm{o}}$ of the $\mathrm{CD}$ treated $S$. aemula was greater (at $P \geq 0.01$ ) than in the other treatments (data not shown).

During the first cycle, there was a decrease of A and E for drought-treated plants on day 10 for L. camara and day 6 for $S$. farinacea (Fig. 3). However, WUE was not different from control in either species (Fig. 4). In L. cardinalis, A was not affected although $\mathrm{E}$ was reduced on day 6, 8, and 10 of the first cycle (Fig. 3 ) thus increasing WUE from day 6 up to $193 \%$ on day 10 (Fig. 4). In S. aemula, A decreased on day 8 and $\mathrm{E}$ on day 6 through
10 (Fig. 3). However, the reduction was lesser for A (Fig. 3), thus causing an increase in WUE on day 8 and $10(170 \%$ and $186 \%$ the $\mathrm{C}$ value, respectively) (Fig. 4).

By the end of the second cycle, DD of three species developed a greater WUE than the other treatments (Fig. 4). Water use efficiency of L. camara CD and DC was similar to the control, whereas in DD it was greater than all other treatments on day 6 and 10 (156\% and 129\% greater than CC, respectively). In $S$. farinacea, drought induced stomatal closure and reduction of $\mathrm{E}$ on day 6 and 8 in $\mathrm{CD}$ (data not shown) and on day 6,8 , and 10 in DD (Fig. 3). The reduced E, coupled with a constant A, resulted in an increase of WUE on DD (144.4\% and $139.6 \%$ the CC value on day 8 and 10, respectively) (Fig. 4). Water use efficiency of $S$. 

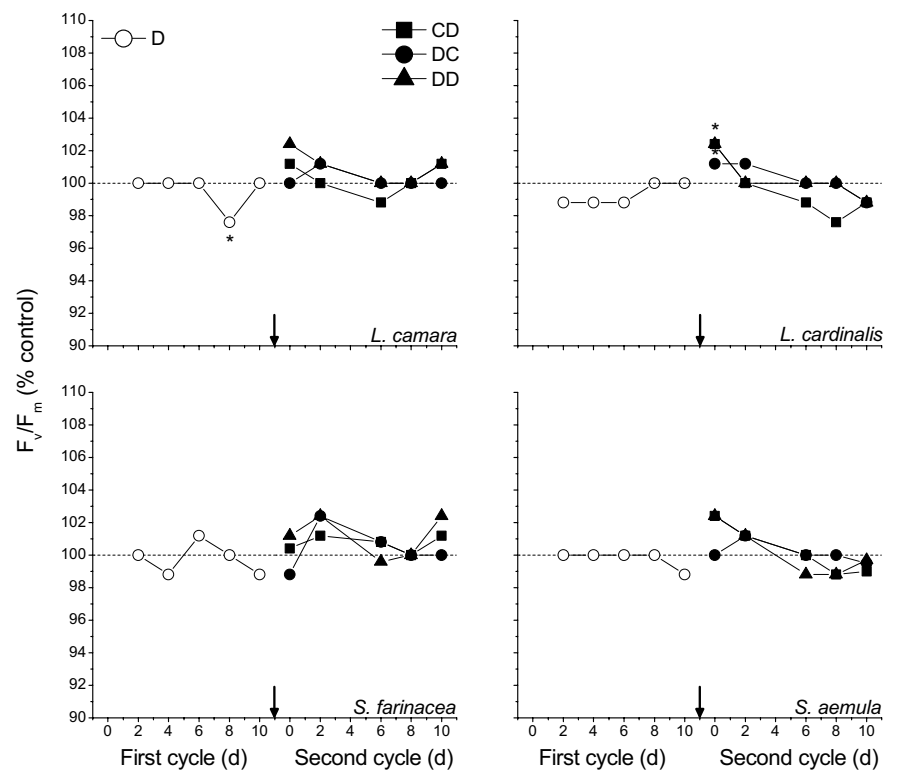

Fig. 2. Photosystem II efficiency $\left(\mathrm{F}_{\mathrm{v}} / \mathrm{F}_{\mathrm{m}}\right)$ of four herbaceous perennial species (Lantana camara, Lobelia cardinalis, Salvia farinacea, and Scaevola aemula) subjected to two consecutive 10-d drought cycles. Means $(n=5)$ for a particular species are expressed as percent of control (plants grown in well-watered substrate). First cycle: $\mathrm{D}=$ plants subjected to drought. Second cycle: $\mathrm{CD}=$ plants well-watered in the first cycle and subjected to drought in the second cycle, DC = plants subjected to drought in the first cycle and well-watered in the second cycle, $\mathrm{DD}=$ plants subjected to drought in both cycles. Arrows indicate rewatering of all pots to container capacity. $*$ indicates significantly different means from control $(\mathrm{C}=$ first cycle, $\mathrm{CC}=$ second cycle $)$ within days at $P \leq 0.05$. Mean separation by Fisher's LSD.

aemula on day 6 was greater in CD and DD (149\% and 163\%, respectively). However, on day 10 , WUE dropped to $74 \%$ in CD and DC and was maintained at $135 \%$ in DD. Water use efficiency of L. cardinalis CD and DD was almost double the CC and DC value on day 6 but was the same as CC by day 10 .

Analysis of the parameters derived from the light response curves showed treatments induced differences in $\Phi$ for L. camara, with $C D$ showing the highest value and DC the lowest (Table 3). Differences in $A_{\max }$ among treatments were observed in $L$. cardinalis and $S$. aemula, both with the greatest $\mathrm{A}_{\max }$ measured in DC. In L. cardinalis $\mathrm{A}_{\max }$ was greater in DC than in DD; in $S$. aemula $\mathrm{A}_{\max }$ was greater in $\mathrm{DC}$ than in the other treatments. $\mathrm{R}_{\mathrm{d}}$ of S. farinacea was greatest in CC and DC and lowest in DD.

\section{Discussion}

To withstand conditions of reduced substrate water content, plants need to have adaptation strategies or be able to acclimate. In the current investigation, L. cardinalis and L. camara did not change morphologically due to drought treatments (data not shown). Both $S$. farinacea and $S$. aemula had reductions in some size and/or mass variables (Table 2). These reductions were greatest in plants exposed to both drought cycles (DD). In general, DC plants were not as constrained in growth as CD or DD plants, possibly because of the smaller ratio of plant mass to substrate volume during the first cycle. This was substantiated by the less rapid reduction in substrate water content that occurred during the first cycle compared to the second cycle.

Increase in WUE is a frequent response in drought-stressed plants and it is considered a mechanism for drought resistance
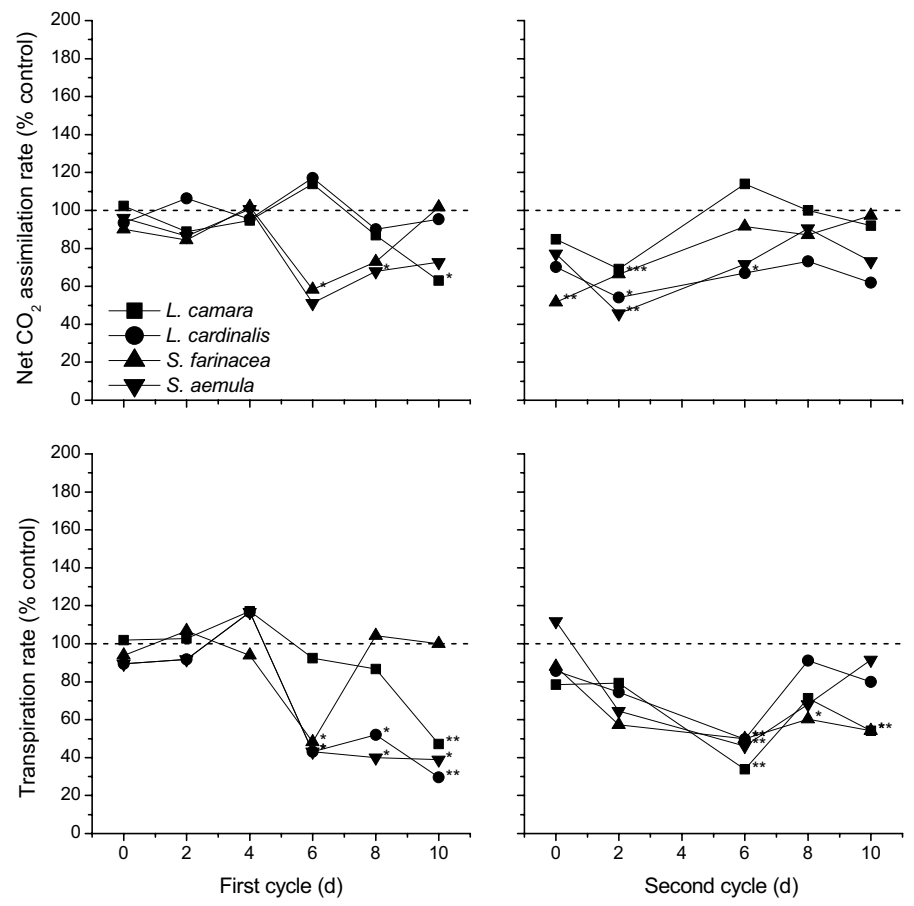

Fig. 3. Net $\mathrm{CO}_{2}$ assimilation rate (top) and transpiration rate (bottom) of four herbaceous perennial species (Lantana camara, Lobelia cardinalis, Salvia farinacea, and Scaevola aemula) subjected to two consecutive 10-d drought cycles. Means $(\mathrm{n}=5)$ for a particular species are expressed as percent of control (plants grown in well-watered substrate). First cycle (left): plants subjected to drought (D). Second cycle (right): plants subjected to drought in both cycles (DD). *, **, *** indicate significantly different means from control $(\mathrm{C}=$ first cycle, $\mathrm{CC}=$ second cycle) within days at $P \leq 0.05,0.01$, or 0.001 , respectively. Mean separation by Fisher's LSD.

(Davies and Lakso, 1979). In L. camara, S. farinacea, and S. aemula, WUE increased with drought stress by the end of the second cycle (Fig. 4), which could be an indicator of a slow adaptation to drought conditions. Vapor pressure deficit was low and either stable or decreasing during both cycles (Fig. 1) and therefore any change of A, E, and WUE during the course of the experiment was not likely due to an increasing water vapor concentration gradient. The only exception was day 6 of the second cycle, when VPD peaked at $1.67 \mathrm{kPa}$. Water use efficiency data (Fig. 4) support the empirical evidence that L. camara, S. farinacea, and S. aemula are more adapted to dry landscapes than $L$. cardinalis. Drought applied in the second cycle caused greater increase in WUE in those plants that had been previously exposed to drought (DD) versus those that had not (CD). This response could have been due to preconditioning, increased plant size (and consequent reduction of available water) or to a passive mechanism to save water, such as loss of turgor.

Chlorophyll fluorescence is an indicator of PSII functioning and electron transfer from PSII to PSI, and it can be used to estimate damage to the photosynthetic system. However, severe drought stress conditions may be required to induce quantifiable reductions in PSII efficiency (Karukstis, 1991). The lack of significant effects of drought on $\mathrm{F}_{\mathrm{v}} / \mathrm{F}_{\mathrm{m}}$ in the present study (Fig. 2) implies that there was little effect of stress on PSII and the primary reactions of photosynthesis. These results were confirmed by the analysis of light response curves which showed no reduction in the photochemical efficiency of PSII (Table 3). Similarly, Percival and Sheriffs (2002) found that $\mathrm{F}_{\mathrm{v}} / \mathrm{F}_{\mathrm{m}}$ was not affected until week 3 of a 70-d drought treatment applied to several woody 

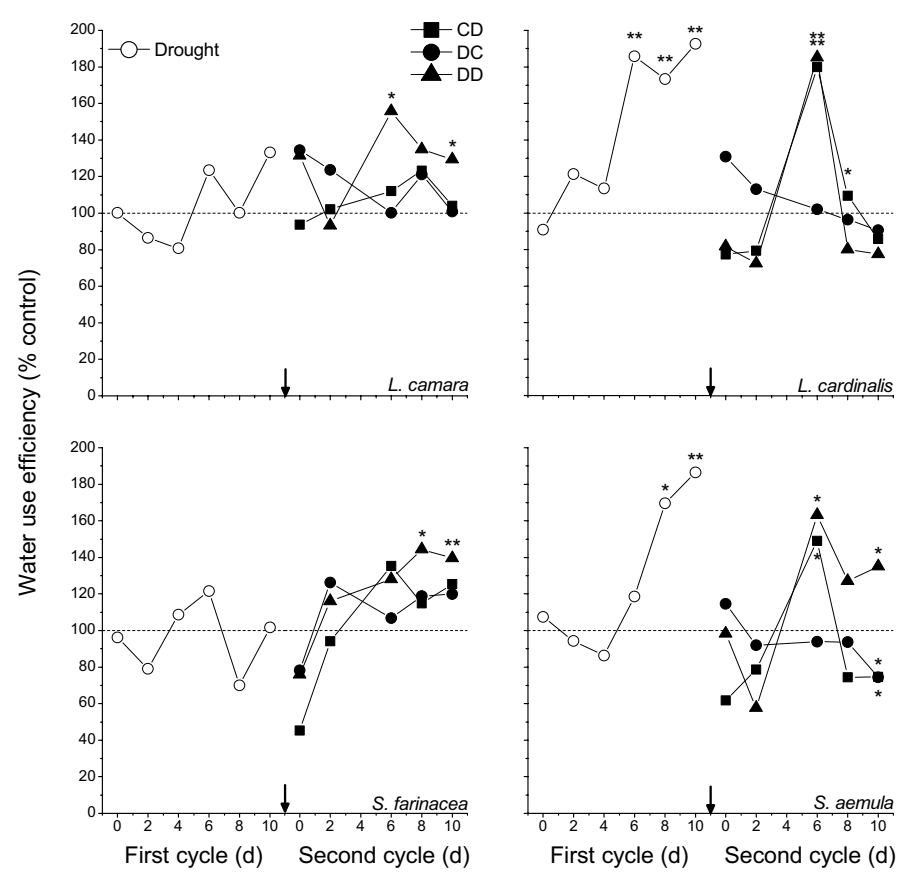

Fig. 4. Water use efficiency of four herbaceous perennial species (Lantana camara, Lobelia cardinalis, Salvia farinacea, and Scaevola aemula) subjected to two consecutive 10 -d drought cycles. Means $(n=5)$ for a particular species are expressed as percent of control (plants grown in well-watered substrate). First cycle: $\mathrm{D}=$ plants subjected to drought. Second cycle: $\mathrm{CD}=$ plants well-watered in the first cycle and subjected to drought in the second cycle, DC = plants subjected to drought in the first cycle and well-watered in the second cycle, $\mathrm{DD}=$ plants subjected to drought in both cycles. Arrows indicate rewatering of pots to container capacity. * ** indicate significantly different means from control $(\mathrm{C}=$ first cycle, $\mathrm{CC}=$ second cycle $)$ within days at $P \leq 0.05$ or 0.01 , respectively. Mean separation by Fisher's LSD.

perennials in a greenhouse under $250 \mu \mathrm{mol} \cdot \mathrm{m}^{-2} \cdot \mathrm{s}^{-1} P P F D$. Feser et al. (2005) reported that $\mathrm{F}_{\mathrm{v}} / \mathrm{F}_{\mathrm{m}}$ for drought-stressed mexican elder (Sambucus mexicana Presl.) was the same as controls after five drought cycles over $165 \mathrm{~d}$. Another possible reason for the lack of differences in $\mathrm{F}_{\mathrm{v}} / \mathrm{F}_{\mathrm{m}}$ could be due to light intensity. The light intensity to which plants were exposed while grown in the greenhouse may have minimized damage to PSII caused by photoinhibition, which has been observed in droughted plants grown at high light intensity (Genty et al., 1987; Massacci and Jones, 1990). When irrigation was withheld for $15 \mathrm{~d}$ on weeping lovegrass [Eragrostis curvula (Schrad.) Nees], a $\mathrm{C}_{4}$ grass grown in a greenhouse at $600-800 \mu \mathrm{mol} \cdot \mathrm{m}^{-2} \cdot \mathrm{s}^{-1}$, differences in $\mathrm{F}_{\mathrm{v}} / \mathrm{F}_{\mathrm{m}}$ appeared on day 10 and continued for the duration of the treatment (Colom and Vazzana, 2003).

An increase in $\mathrm{F}_{\mathrm{o}}$, frequently associated with a decrease in $\mathrm{F}_{\mathrm{v}} / \mathrm{F}_{\mathrm{m}}$, is considered as a reliable diagnostic indicator of photoinhibition and structural damage to the PSII reaction center complex (Karukstis, 1991; Maxwell and Johnson, 2000). Percival and Sheriffs (2002) reported alterations in $\mathrm{F}_{\mathrm{o}}$ were detected earlier than changes in $\mathrm{F}_{\mathrm{v}} / \mathrm{F}_{\mathrm{m}}$ and therefore represent a more efficient tool to rapidly assess impairment of the photosynthetic apparatus. According to this assumption, the increase in $\mathrm{F}_{\mathrm{o}}$ seen in our study in $S$. aemula on the last day of the second cycle (data not shown) could indicate the onset of decreased photochemical efficiency.

The overall plant quality was not affected during the experiment despite lowering substrate water content to values as low as $0.13 \mathrm{~mm}^{3} \cdot \mathrm{mm}^{-3}$ and repeated wilting during the last part of both cycles. This level of substrate water was sufficient for growth and development of these species in potted conditions and shows the conventional method of producing plants at container capacity may result in excess irrigation and waste water. Similarly, gas exchange, chlorophyll fluorescence, and leaf water potential were not affected at substrate volumetric water content $\geq 0.22$ $\mathrm{mm}^{3} \cdot \mathrm{mm}^{-3}$ for Impatiens wallerana Hook. and Salvia splendens Sell ex Roem. \& Schult. and $\geq 0.15 \mathrm{~mm}^{3} \cdot \mathrm{mm}^{-3}$ for Catharanthus roseus (L.) G. Don and Petunia $\times$ hybrida hort. Vilm.-Andr. (Nemali and van Iersel, 2005). Lower substrate water content during production would serve to reduce water use and fertilizer runoff, lower production costs and increase sustainability without compromising plant quality. In the future, irrigating plants according to their water requirement could not only reduce water use but may acclimate plants for drought tolerance in the landscape (Armitage and Kowalski, 1983; Eakes et al., 1991; Kozlowski and Pallardy, 2002).

Our study showed promising yet not conclusive evidence that plants could be screened for high WUE under greenhouse conditions to determine if they are suitable candidates for xeriscapes. Future studies to evaluate drought stress responses in herbaceous perennials grown in greenhouse conditions may warrant extending the duration of the drought cycle(s), and/or increasing light intensity to accelerate the onset and prolong the response mechanisms. Field data would add additional support for recommending species with potential use for xeriscapes.

\section{Literature Cited}

Armitage, A.M. 2001. Armitage's manual of annuals, biennials, and half-hardy perennials. Timber Press, Portland, Ore.

Armitage, A.M. and T. Kowalski. 1983. Effect of irrigation frequency during greenhouse production on the postproduction quality of Petunia hybrida Wilm. J. Amer. Soc. Hort. Sci. 108:118-121.

Ball Publishing. 2003. Drought-tolerant plants. Grower Talks 66:7272.

Bhalla, P.L. and K. Sweeney. 1998. Micropropagation of ScaevolaAustralian native of ornamental horticulture. Austral. J. Expt. Agr. 38:399-401.

Colom, M.R. and C. Vazzana. 2003. Photosynthesis and PSII functionality of drought-resistant and drought-sensitive weeping lovegrass plants. Environ. Expt. Bot. 49:135-144.

Davies, F.S. and A.N. Lakso. 1979. Water stress responses of apple trees. I. Resistance and capacitance as affected by greenhouse and field conditions. J. Amer. Soc. Hort. Sci. 104:395-397.

Denver Water Department. 2005. Xeriscape. 15 Dec. 2005. <http://www. water.denver.co.gov/cons_xeriscape/xeriscape/xeriscapeprinciples. html>.

Eakes, D.J., R.D. Wright, and J.R. Seiler. 1991. Moisture stress conditioning effects on Salvia splendens 'Bonfire'. J. Amer. Soc. Hort. Sci. 116:716-719.

Feser, C., R. St. Hilaire, and D. VanLeeuwen. 2005. Development of in-ground container plants of mexican elders exposed to drought. HortScience 40:446-450.

Genty, B., J.-M. Briantais, and N.R. Baker. 1987. Effects of drought on primary photosynthetic processes of cotton leaves. Plant Physiol. $83: 360-364$

Greer, D.H. 1995. Effect of canopy position on the susceptibility of kiwifruit (Actinidia deliciosa) leaves on vines in an orchard environment to photoinhibition throughout the growing season. Austral. J. Plant Physiol. 22:299-309.

Griffiths, M. 1994. Index of garden plants. Macmillan, London.

Henckel, P.A. 1964. Physiology of plants under drought. Annu. Rev. Plant Physiol. 15:363-386.

Hsiao, T.C. 1973. Plant responses to water stress. Annu. Rev. Plant Physiol. 24:519-570. 
Table 3. Parameters derived from the analysis of light response curves of four herbaceous perennial species (Lantana camara, Lobelia cardinalis, Salvia farinacea, and Scaevola aemula) subjected to two consecutive 10-d drought cycles.

\begin{tabular}{|c|c|c|c|c|}
\hline \multirow[b]{2}{*}{ Species } & \multicolumn{4}{|c|}{ Light response parameters ${ }^{z}$} \\
\hline & Treatment ${ }^{\mathrm{y}}$ & $\begin{array}{c}\Phi \\
\mathrm{mol} \cdot \mathrm{mol}^{-1} \text { (quanta) }\end{array}$ & $\begin{array}{c}\mathrm{A}_{\max } \\
\left(\mu \mathrm{mol} \cdot \mathrm{m}^{-2} \cdot \mathrm{s}^{-1}\right)\end{array}$ & $\begin{array}{c}\mathrm{R}_{\mathrm{d}} \\
\left(\mu \mathrm{mol} \cdot \mathrm{m}^{-2} \cdot \mathrm{s}^{-1}\right)\end{array}$ \\
\hline \multirow[t]{4}{*}{ L. camara } & $\mathrm{CC}$ & $0.09 \mathrm{bc}^{\mathrm{x}}$ & 18.5 & 1.80 \\
\hline & $\mathrm{CD}$ & $0.12 \mathrm{a}$ & 15.4 & 1.57 \\
\hline & DC & $0.08 \mathrm{c}$ & 20.8 & 2.06 \\
\hline & DD & $0.09 \mathrm{~b}$ & 20.3 & 1.38 \\
\hline \multirow[t]{4}{*}{ L. cardinalis } & $\mathrm{CC}$ & 0.09 & $10.5 \mathrm{ab}$ & 1.48 \\
\hline & $\mathrm{CD}$ & 0.09 & $7.6 \mathrm{ab}$ & 1.11 \\
\hline & DC & 0.09 & $12.7 \mathrm{a}$ & 1.73 \\
\hline & DD & 0.09 & $4.4 \mathrm{~b}$ & 0.83 \\
\hline \multirow[t]{4}{*}{ S. farinacea } & $\mathrm{CC}$ & 0.08 & 9.1 & $2.27 \mathrm{a}$ \\
\hline & $\mathrm{CD}$ & 0.09 & 13.7 & $1.54 \mathrm{~b}$ \\
\hline & DC & 0.08 & 14.1 & $2.80 \mathrm{a}$ \\
\hline & DD & 0.09 & 14.0 & $0.57 \mathrm{c}$ \\
\hline \multirow[t]{4}{*}{ S. aemula } & $\mathrm{CC}$ & 0.09 & $10.1 \mathrm{~b}$ & 1.55 \\
\hline & $\mathrm{CD}$ & 0.09 & $9.9 \mathrm{~b}$ & 1.07 \\
\hline & DC & 0.08 & $18.0 \mathrm{a}$ & 1.70 \\
\hline & DD & 0.09 & $9.6 \mathrm{~b}$ & 1.09 \\
\hline $\begin{array}{l}{ }^{{ }^{2} \Phi=\text { apparen }} \\
\text { tion. } \\
{ }^{y} C C=\text { plants } \\
\text { and subjected } \\
\text { watered in the } \\
{ }^{x} \text { Means follow }\end{array}$ & $\begin{array}{l}\mathrm{n} \text { yield, } \mathrm{A}_{\text {max }} \\
\text { well-watere } \\
\text { ht in the secc } \\
\text { cycle, DD = } \\
\text { fferent letter }\end{array}$ & $\begin{array}{l}\text { ght-saturated rate of } \\
\text { strate in both cycles, } \\
\text { ycle, DC = plants subj } \\
\text { s subjected to drough } \\
\text { significantly different }\end{array}$ & $\begin{array}{l}\mathrm{CO}_{2} \text { assimilatio } \\
\text { plants well-wat } \\
\text { to drought in th } \\
\text { th cycles. } \\
\leq 0.05 \text { by Fisher }\end{array}$ & $\begin{array}{l}=\text { dark respira- } \\
n \text { the first cycle } \\
\text { cycle and well- } \\
n=5 \text {. }\end{array}$ \\
\hline
\end{tabular}

Iljin, W.S. 1957. Drought resistance in plants and physiological processes. Annu. Rev. Plant Physiol. 8:257-274.

Karukstis, K.K. 1991. Chlorophyll fluorescence as a physiological probe of the photosynthetic apparatus, p. 769-795. In: H. Sheer (ed.). Chlorophylls. CRC, Boca Raton, Fla.

Knowles, T.C., B.W. Hipp, and M.A. Hagemann. 1993. Container medium and slow-release nitrogen fertilizer influence growth and quality of Salvia farinacea. HortScience 28:623-625.

Kozlowski, T.T. and S.G. Pallardy. 2002. Acclimation and adaptive responses of woody plants to environmental stresses. Bot. Rev. 68:270-334.

Kramer, P.J. and J.S. Boyer. 1995. Water relations of plants and soils. Academic, San Diego.

Kuack, D. 2003. Will drought restrictions limit plant offerings? Greenhouse Mgt. Production 23:2-2.

Lambers, H., F.S. Chapin III, and T.L. Pons. 1998. Plant physiological ecology. Springer-Verlag, New York.

Massacci, A. and H.G. Jones. 1990. Use of simultaneous analysis of gas exchange and chlorophyll fluorescence quenching for analyzing the effects of water stress on photosynthesis in apple leaves. Trees 4:1-8.
Maxwell, K. and G.N. Johnson. 2000. Chlorophyll fluorescence-A practical guide. J. Expt. Bot. 51:659-668.

Nemali, K.S. and M.W. van Iersel. 2005. Water requirements and drought tolerance of bedding plants. HortScience 40:1115. (Abstr.)

Percival, G.C. and C.N. Sheriffs. 2002. Identification of drought-tolerant woody perennials using chlorophyll fluorescence. J. Arboricult. 28:215-221.

Robichaux, R.H. and R.W. Pearcy. 1984. Evolution of C-3 and C-4 plants along an environmental moisture gradient-Patterns of photosynthetic differentiation in Hawaiian Scaevola and Euphorbia species. Amer. J. Bot. 71:121-129.

Thompson, S.W. and T.G. Lammers. 1997. Phenetic analysis of morphological variation in the Lobelia cardinalis complex (Campanulaceae: Lobelioideae). Syst. Bot. 22:315-331.

Welch, W.C. 1989. Perennial garden color. Taylor Publishing Co., Dallas.

Welsh, D.F., W.C. Welch, and R.L. Duble. 2000. Landscape water conservation. Xeriscape ${ }^{\mathrm{TM}}$. 19 Jan. 2006. <http://aggie-horticulture.tamu. edu/extension/xeriscape/xeriscape.html>. 